\title{
Rejseserien - mellem engagerende journalistik, forbrugerorientering og tv-underholdning
}

\section{Analyse af rejseserier vist på dansk fjernsyn i perioden 1988-2005}

\author{
AF MAJA SONNE DAMKJAR
}

OG ANNE MARIT WAADE

\begin{abstract}
Rejseserier har længe været en populær fjernsynsgenre, men forskningen på feltet er stadig meget begrænset. Artiklen tager afsæt $\mathrm{i}$ international og dansk forskning i rejseserier som journalistisk felt. Der argumenteres for, at rejseserier ikke kan vurderes ud fra traditionelle journalistiske kriterier alene, da genren i lighed med livsstilsserier har underholdning som væsentlig præmis. Rejseserien bestemmes som en genrehybrid, der er udspændt mellem tre supertekstgenrer: journalistisk dokumentar, tv-underholdning og forbrugeroplysning. Denne karakteristik danner grundlag for en tentativ kortlægning af rejseserier på danske tv-kanaler i perioden 1988-2005', hvor 10 prototyper bestemmes ud fra bl.a. valg af programvært og rejseform. Afslutningsvist diskuteres undersøgelsens genreteoretiske perspektiver i relation til den empiriske analyse med fokus på rejseserien som genrehybrid.
\end{abstract}

\section{Rejsejournalistik og livsstilsmedier}

Rejseprogrammerne er udtryk for den internationale livsstilsbølge, der ikke blot er skyllet ind over udbuddet på de danske tv-kanaler de seneste 20 år (Lykke Christensen 2010), men har 
opblødt de journalistiske genrer og aflejret sig i en væsentlig del af det samlede medieudbud i perioden. Således vokser omfanget af rejsejournalistik både på internettet, i dagspressens faste spalter og avistillæg samt i fjernsynet, hvor rejseserier sammen med andre livsstilsprogrammer om bl.a. mad, interiør, mode, hus, have og sundhed bruges til kanalprofilering og for at sikre seertal.

Det forskningsspørgsmål, der ligger til grund for vores teoretiske og empiriske analyse, er, hvad der karakteriserer rejseserien som genre og som medieprodukt på danske tv-kanaler?

Undersøgelser af denne art er nødvendige, for forskningen i rejseserier er sparsom og i overvejende grad domineret af en nyhedsjournalistisk optik, der mangler blik for en helt konstituerende del af genren: underholdningsdimensionen. Det nødvendiggør forskningsbidrag med et bredere medievidenskabeligt sigte, der gør det muligt at udpege en række væsentlige sammenhænge og tendenser ved disse medieprodukter, som har betydning for forståelsen af rejseseriernes underholdende karakter. Behandlingen af underholdningsaspektet er desuden af formidlingsmæssig interesse, for som Lars Kabels undersøgelser påpeger, er underholdende fremstillinger mere tilbøjelige til at engagere seeren end konfliktorienteret udlandsdækning. Det at blive 'holdt under' og underholdt kan dermed ikke affejes som noget "blot". Underholdning må her forstås som den særlige måde, hvorpå medieteksten forsøger at engagere sin seer, f.eks. ved at lade denne relatere sig til sig selv og sin omverden gennem nydelse, absorption og forbrug.

Vores teoretiske undersøgelse omfatter en analyse og diskussion af væsentlige internationale og skandinaviske bidrag på feltet og udgør fundamentet for vores empiriske undersøgelse af samtlige rejseserier vist på seks danske tv-kanaler i perioden 1988-2005. Foruden en indsnævring af udsendelsestidspunkt og format har vi screenet alle udsendelser, der indeholder et rejseelement, på baggrund af en definition af rejseserier som tvudsendelser, der har rejsen, turguidning eller et turist-blik på steder (Urry 2002) som en konstituerende del af sit koncept ${ }^{2}$.

Med denne artikel ønsker vi at bidrage til den medievidenskabelige og journalistiske forskning gennem en teoretisk og empirisk belysning af rejseserien som medieprodukt og genrehybrid. 


\section{Teoretiske perspektiver på rejseserier som mediegenre}

Som optakt til vores empiriske analyse af rejseserier vil vi i det følgende præsentere og diskutere fremtrædende synspunkter og perspektiver på rejsejournalistik, rejseserier og livsstilsjournalistik inden for aktuel teori og forskning i henholdsvis international og skandinavisk sammenhæng.

På trods af rejseseriernes udbredelse er forskningen i rejseserier af meget begrænset og sporadisk karakter (Fürsich 2002a). Dette hænger sammen med en generel mangel på forskning i området. Til trods for at livsstil som medie- og tv-underholdning har haft omfattende forskningsmæssig opmærksomhed gennem de seneste par årtier parallelt med stofområdets udvikling og prægning af fjernsynets programudbud (Bell og Hallows 2005, Bonner 20003, Palmer 2008), har studier af rejseserier været beskedne. Relationen mellem medier og turisme er blevet forholdsvist grundigt belyst både teoretisk og empirisk inden for turisme- og marketingstudier (bl.a. Urry 2002, Crouch et al 2005 ), men i langt mindre grad inden for journalistik- og medieforskningen (Jensen og Waade 2009). Helt symptomatisk for feltet findes der f.eks. ingen egentlig definition af begrebet rejsejournalistik. Manglen på begrebsafklaring afspejler sig også i journalistisk terminologi, f.eks. bruges de engelske betegnelser "travel journalist" og "travel writer" om hinanden og indikerer hermed genrens slægtskab med henholdsvis nyhedsjournalistikken og rejsebeskrivelsen som litterær genre (Hanusch 2010).

Den australske forsker Folker Hanusch arbejder med journalistiske former, der eksisterer i skyggen af nyhedsforskningens generelle dominans, bl.a. kriminaljournalistik samt livsstils- og rejsejournalistik. I en artikel i Journalism Studies (Hanusch 2010) præsenterer forfatteren et omfattende studie af rejsejournalistikkens aktuelle teoretiske og forskningsmæssige bidrag helt frem til i dag. Han fremhæver fire dimensioner i den eksisterende forskning og udpeger samtidig en række af feltets udfordringer og mangler. Dimensionerne omfatter forskning i rejsejournalistikkens produktionsforhold, stofområde samt tekstlige og diskursive karakteristika. Den første dimension, rejsejournalistikkens kulturelle repræsentationer, har haft den største forskningsmæssige bevågenhed, bl.a. med fokus på, hvordan rejseprogrammer 
og rejseartikler fremstiller fremmede kulturer og "den anden". Eksempelvis har den amerikanske journalistikforsker Elfriede Fürsich (2002a, 2002b) med baggrund i antropologi og journalistik karakteriseret rejseserier (Travellers, Rough Guide, Lonely Planet) som global journalistik, der indeholder særegne turistrelaterede måder at forstå og fremstille den rejsende og fremmede kulturer på. Hanusch' anden dimension, rejsejournalistikkens markedsorientering, handler om stofområdets publikumsappel. Han præsenterer forskning, der på forskellig vis belyser forholdet mellem information og underholdning, og fremhæver bl.a. Hanitzsch (2007), der skelner mellem journalistik, der har offentlighedens interesse for øje, og journalistik, der orienterer sig mod individuelle forbrugeres ønsker og behov og betoner de underholdende elementer i formidlingen (ibid.). I den forbindelse efterlyser Hanush empirisk forskning, der belyser journalisternes intentioner og holdninger samt publikums faktiske interesser.

Hanush' tredje dimensionen drejer sig om journalistens grundlæggende motivation: Forholder journalisten sig kritisk til turisme, eller er denne snarere med til at fejre og betone de positive sider af rejselivet? Han nævner bl.a. Fürsichs (op.cit.) analyser af rejseseriers eksplicitering af forskellige typer turisme som udtryk for en kritisk stillingtagen og ikke mindst Lischke (2006), der peger på to forskellige typer rejsejournalister: de, hvis motivation primært er knyttet til journalistikkens traditionelle (kritiske) idealer, og de, hvis motivation mere er forankret i muligheden for og fornøjelsen ved at rejse. Den fjerde dimension kredser om rejsejournalistikkens etiske aspekter og tager afsæt i det faktum, at rejsejournalister, der typisk er freelancere, ofte er sponsoreret af aktører i rejsebranchen og dermed tilbøjelige til at fremstille de forskellige rejsemål på en positiv og fristende måde. I forlængelse heraf efterspørger Hanusch mere forskning, der belyser den nære forbindelse mellem turismeindustri og rejsejournalistik, både den eksplicitte, i form af sponsorering og redaktionelt samarbejde, og den mere implicitte, i form af rejsejournalistikkens fejring og positive omtale af turisme.

Hanusch' grundige undersøgelse af forskningen i rejsejournalistik er prisværdig, og han er med til at synliggøre rejsejournalistik som henholdsvis journalistisk praksis og forskningsfelt. Han præsenterer feltet ud fra en traditionel journalistisk optik, 
hvor idealer om bl.a. fri presse, kritisk journalistik, nyhedskriterier og kildekritik er i højsædet. Hans fire dimensioner udpeger aktuelle og relevante diskussioner i forhold til rejsejournalistik generelt og rejseserier specifikt, men de indfanger ikke rejseseriernes hybride genrekarakter eller betydningen af den mediespecifikke kontekst. Ligeledes forbliver rejsejournalistikkens underholdende karakter ubelyst. Vi mener, at denne snævre (nyheds-) journalistiske optik på rejsejournalistik er mangelfuld, fordi den ikke forholder sig til underholdningsaspektet som en konstitutiv del af genren.

I nordisk sammenhæng findes der kun enkelte forskningsbidrag, der belyser rejseserier, og disse retter primært fokus mod rejsejournalistikkens diskursive fremstilling af omverden. I denne sammenhæng skal Kristin Orgerets (2002) analyse af norske rejseserier næves, hvori hun udpeger og diskuterer de nationale diskurser, der er i spil i rejseserien som genre. Ligeledes bør Lars Kabels Verden langt herfra (2005) fremhæves for sin omfattende komparative analyse af nyheder, fakta-programmer og rejseseriers dækning af den tredje verden i dansk fjernsyn. På baggrund af et datamateriale, der både indeholder tekstanalyser af udvalgte programmer, seertal samt receptionsanalyser og interviews med journalister og producenter, diskuterer han, hvordan nyhedernes konfliktorienterede form mister seernes interesse og engagement til fordel for fakta-programmernes og ikke mindst rejseseriernes (bl.a. Michael Palin, Vagn Olsen og Thomas Breinholt/På kanten af verden) mere konfliktfrie og underholdende fremstillingsformer. Ifølge Kabels undersøgelse foretrækker seerne rejseseriernes dramaturgiske konflikter (som f.eks. i På kanten af verden) frem for nyhedernes journalistiske konflikter. Kabel fremhæver humor, identifikation og drama som væsentlige måder at engagere seerne på i forhold til fremmede kulturer: "Mens nyhedsdækningen (...) handlede om Vestens konfrontationer med den arabiske verden og islam, så udfoldede faktaprogrammerne en bredere del af verden og tilværelsen og bragte den fjerne verden tættere på de danske seere.” (Kabel 2005:66).

Det, der savnes i Kabels rapport, er en mere nuanceret diskussion af programmernes meget forskellige kommunikative præmisser og af, hvordan rejsemålene indgår i væsensforskellige kontekster. Han bruger f.eks. begreber som udland, tredje ver- 
den, fremmede kulturer og udviklingslande, men disse betegnelser er i sig selv diskursivt bestemmende både i forhold til, hvilke typer programmer og indslag der analyseres, og hvordan disse skal forstås. I forhold til rejseserien som genre er det nogle helt bestemte kvaliteter ved stederne, der fremhæves; netop som destinationer og steder, der på forskellig vis kan forbruges. F.eks. præsenteres Malaysia, Stockholm, Grønland og Sahara som samme type sted: nemlig som potentielle rejsemål. Men betegnelsen "udviklingsland" indikerer en helt anden diskursiv tilgang til stedet og landet. Det virker underligt, at de fristende rejsebeskrivelser sidestilles og sammenlignes med nyhedsdækningen af f.eks. Irak-krigen. På den anden side illustrerer rapporten på glimrende vis de mange ulige præmisser, der gælder fjernsynets fakta-formidling.

Det kan virke paradoksalt, at mens Hanusch med referencer til Lischke og Fürisch efterspørger mere kritiske vinkler på rejsejournalistikkens turismerelation, så efterspørger Kabel en udlandsdækning, der er mindre konfliktfikseret, mere vedkommende og engagerende for læseren. Årsagen til denne modsætning er for det første, at rejse i sig selv ikke findes som et konstitueret journalistisk felt, og for det andet, at Kabel og Hanusch undersøger dette "felt" fra forskellige vinkler. Det, der savnes hos dem begge, er en højere grad af problematisering af rejsejournalistik som felt. En beskrivelse af feltets - i Bourdieus forstand - grundlæggende præmis, aktører, motivation og grænser ville være med til at udpege forskellen på henholdsvis nyheds- og livsstilsjournalistik og klargøre, at der er tale om to meget forskellige felter. Rejsebeskrivelser, rejsejournalistik og udlandsdækning har nogle umiddelbare fælles træk, men hviler på grundlæggende forskellige journalistiske traditioner, motivationer og præmisser, og redaktionelt er de placeret forskellige steder, f.eks. som avistillæg, i hverdagens faktuelle underholdningsflade og som udlandssektion i en avis eller nyhedsudsendelse.

Efter vores vurdering skal rejsejournalistik først og fremmest ses i lyset af livsstilsjournalistikkens karakter og udbredelse. For at belyse rejseseriernes underholdende karakter vil vi derfor inddrage teori om livsstilsjournalistikkens særlige form og præmis samt undersøgelser af livsstilsprogrammernes mediespecifikke og underholdende særtræk. Unni From (From 2007, From \& 
Waade 2007) har undersøgt livsstilsjournalistik i danske aviser og sammenhængen mellem forbrugerjournalistik i et historisk perspektiv og dagens mere livsstilsprægede servicejournalistik. From skriver, at livsstilsjournalistikkens grundlæggende appel til læseren drejer sig om nytte og nydelse. Nytte handler om at få praktisk information og demonstration som forbruger, mens nydelse omfatter de positive, æstetiske og følelsesstimulerende oplevelser, stofområdet lægger op til hos mediebrugerne i kraft af bl.a. billeder, drømmescenarier og sansebaserede beskrivelser. Derfor er kritisk stillingtagen til turisme eller fremmede kulturer ikke rejsejournalistikkens ærinde som sådan, den hører derimod hjemme i andre journalistiske felter og genrer. Det er dog ikke ensbetydende med, at journalistisk etik og etikette ikke vedrører produktionen af rejseserier, hvilket illustreres af DR1's aflysning af Karsten Kjærs bekostelige rejseserie Rejsen til Paradis (2005) med henvisning til seriens ukritiske skildring af blandt andet diktaturstaten Burma og hungersnødsramte Etiopien som paradisiske turistdestinationer. I en aktuel bog belyser Unni From og Nete Nørgaard Kristensen (2011) videre livsstilsjournalistik som en art kulturjournalistik, hvor de lægger det brede kulturbegreb til grund, og hvor det, der karakteriserer kultur- og livsstilsjournalistik i aktuelle danske dagblade, er en bred interesse blandt publikum for at lade sig adsprede, underholde, opdatere og skabe identitet og fælleskaber (From \& Kristensen 2011: 193ff).

Rejseserien har rødder i de trykte mediers rejsejournalistik, men er audiovisuel, og dette mediespecifikke forhold betyder, at vi må vende os mod forskningen i tv-underholdning for at få øje på væsentlige karakteristika ved genren. Ganske som i tv-livsstilsunderholdning spiller værten i rejseprogrammer en særlig rolle sammen med indholdet af elementer fra andre faktuelle underholdningsprogrammer, f.eks. konkurrencer, quiz, make-over (Dunn, 2005a, 2005b). Programværten spiller ofte en helt afgørende rolle for at sikre seerens fascination og opmærksomhed. Her er serieformatets strukturerende princip desuden af væsentlig betydning. Rejseserierne indgår som en del af den faktuelle tv-underholdning, der har oplevelse, hverdagslighed og socialitet som væsentlige kendetegn, og typisk sendes en rejseserie i samme time slot hver uge, så seeren har mulighed for at opbygge forventninger til og ritualisere sofarejsen. Programværten skal 
sikre sammenhæng mellem de enkelte episoder og skabe kontakt og intimitet mellem programmets deltagere, seere og destinationer. Ofte er værten en kendt mediepersonlighed, hvilket i sig selv kan virke underholdende og relationsskabende, og han/hun kan videre være med til at præge programmet på en underholdende måde gennem f.eks. overdrivelse, underdrivelse, biografiske referencer eller ved at indgå i komiske situationer (f.eks. Anders Lund Madsens, Thomas Breinholts eller Ian Wrights rejseserier). Vores teoretiske analyse viser, at rejsejournalistik bør anskues i lyset af en generel opblomstring af livsstilsjournalistikken, som netop henvender sig til sin læser som borger, klient, hedonist og forbruger (Unni From, 2007).

Rejseserier har rod i rejsejournalistikken og engagerer seerne gennem drama, humor og identifikation, men er i sagens natur audiovisuelle. Derfor bør forskningen have blik for de mediespecifikke karakteristika, som har betydning for de enkelte seriers underholdende karakter, herunder værtsrollen, rejseformen og inspirationen fra andre tv-genrer. Rejseserier må derfor forstås som en genrehybrid, der blander elementer fra andre genrer og diskursive praksisser, og det er netop blandingsforholdet og den konstante genremæssige forhandling med publikum, der karakteriserer rejseserier og faktuel tv-underholdning som mediefænomen (Hill 2007).

\section{Udgangspunkt for empirisk undersøgelse}

I forlængelse af vores teoretiske analyse og som udgangspunkt for vores kortlægning af rejseserier på dansk tv vil vi argumentere for, at rejseserien i sin grundform er udspændt mellem de tre supertekstgenrer: den journalistiske dokumentar, faktuel tvunderholdning og forbrugerorientering, som fordrer hver sin kommunikative intentionalitet (Scannell 1994:41) og receptionsmodus (Nichols 2001). 


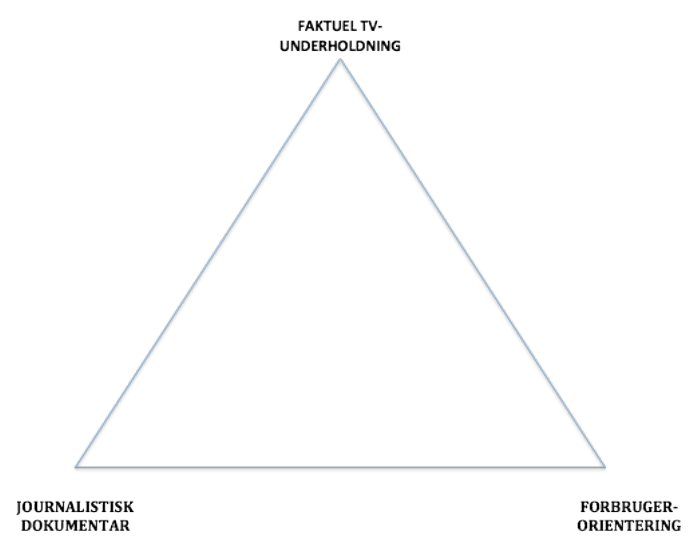

Forbrugerorientering har som primær intention at overbevise og påvirke seeren i forhold til forbrugeradfærd (f.eks. New Scandinavian Cookings rejse- og madserier, bl.a. Tinas Køkken), mens den journalistiske dokumentar tiltaler modtageren som demokratisk borger og har som sit primære formål at oplyse, skabe en kritisk offentlighed og myndiggøre individer (f.eks. DR Explorer, DR2 og DR1). Tv-underholdning på sin side tiltaler modtageren som mediebruger og har som sit primære formål at fange og fastholde seerens interesse ved hjælp af bl.a. æstetisk nydelse, humor, spænding og seerinvolvering, f.eks. serier som På kanten af verden med Thomas Breinholt (TV2), Jakob og Lotte på nye eventyr (TV3) og Signe og BS på afveje (TV2) (se også Waade 2010, Waade 2009, Bruun og Frandsen, 2010:17). Rejseseriernes receptionsmodus vil afspejle balanceforholdet mellem de tre supertekstgenrer og er delvist afhængig af brugskonteksten, f.eks. kan den samme rejseserie fungere som skolefjernsyn om formiddagen og som faktuel hverdagsunderholdning i prime time. Mens journalistik og reklame har en kommunikativ intentionalitet, der ligger uden for selve medieteksten, har medieunderholdning sig selv som primært formål. Når vi betragter rejsejournalistik som underholdning, er det netop som former for journalistik, der i udtalt grad har sig selv som sit primære mål: at fange og fastholde seerens/læserens interesse. Dette stofområde udnyttes også i mediernes strategiske overvejelser; omfanget af underholdning, der kan fange og fastholde publikums interesse, f.eks. på en tvkanal, kan være med til at sikre kundegrundlag og markedsandel. 
Dette gælder både magasiner, dagspresse og tv-kanaler.

I vores analyse vil vi vise, hvordan de forskellige rejseserier forholder sig til de tre supertekstgenrer journalistisk dokumentar, faktuel tv-underholdning og forbrugerorientering, og hvordan programvært og rejseform udgør kommunikative karakteristika, der kan bruges til at identificere og kategorisere forskellige typer rejseserier. En sådan kategorisering gør det samtidig muligt at skitsere udviklingen af rejseserier på den danske sendeflade.

\section{Undersøgelsesdesign og empirisk afgrænsning}

Udgangspunktet for vores empiriske analyse var ønsket om at karakterisere rejseserien som genre og medieprodukt på de danske tv-kanaler gennem en tentativ kortlægning af det brogede og underbelyste felt af rejseserier, der efter DR's monopolbrud blomstrede op som tv-underholdning på den danske sendeflade. Vi har valgt at afgrænse den empiriske analyse til rejseserier sendt i Danmark, da mange rejseserier er produceret med et lokalt sprogfællesskab for øje, hvilket afspejler sig i valg af lokalkendte værter og deltagere, og en vurdering af disse aspekter kræver indgående kendskab til det kulturfællesskab, medieteksten udspringer af og er indlejret i. Desuden muliggjorde indsnævringen til Danmark, at vores undersøgelse kunne kaste lys over et underbelyst felt i dansk tv-forskning og give indblik i danske kanalers rejseserieudbud i relation til deres kanalprofil og dermed muliggøre en diskussion af, hvorvidt og hvordan rejseserier kan siges at være journalistik.

Som udgangspunkt for en kortlægning af danske rejseserier efter monopolbruddet udformede vi et undersøgelsesdesign inspireret af den kvantitative metode indholdsanalyse, hvis principper gør det muligt at undersøge det manifeste indhold i store mængder tekst og samtidig tilgodese de traditionelle (natur) videnskabelige krav om objektivitet, validitet og reliabilitet (van Zoonen 1994:69). Selv om indholdsanalysen tilstræber objektivitet, er det væsentligt at bide mærke i, at der allerede i udvælgelsen af det empiriske materiale er tale om et subjektivt valg. Dette gælder i endnu højere grad for næste skridt i processen, hvor det er nødvendigt at beslutte sig for, hvilke variabler man ønsker undersøgt (Ibid. s. 70). En måde at imødekomme denne 
subjektivitet på er ved at sikre gennemsigtighed og gennemskuelighed i undersøgelsen, hvorfor vi underbygger vores empiriske analyse med tabeller og modeller.

Analysens genstandsfelt er rejseserier sendt i prime time fra 1988 til 2005 på de to public service-kanaler DR1 og TV2 samt deres søsterkanaler DR2, TV2 Charlie, TV2 Zulu samt den reklamefinansierede kanal TV3. Vi har valgt prime time, programmer som bliver påbegyndt i tidsrummet 19-22, som afgrænsning, da netop dette sendetidspunkt op gennem 1990'erne er blevet fyldt med tv-programmer med forlæg i ugeblade og magasiners livsstils- og forbrugerjournalistik, særligt på de to public servicekanaler i den tidlige aftenstund (Christensen 2009:23). Programmer i dette tidsrum er typisk tilrettelagt med underholdning for øje. Vores afgrænsning indebærer hermed, at rejseserier sendt om for- og eftermiddagen, som typisk sigter på fakta-oplysning og undervisning, ikke er medtaget. En anden væsentlig afgrænsning er, at vi udelukkende har valgt at medtage rejseserier (min. to afsnit) i undersøgelsen, hvilket indebærer, at selvstændige udsendelser, der kan kategoriseres som "rejse-tv", er frasorteret. Denne formatafgrænsning er vigtig, da et væsentligt karakteristikum for rejse-tv med rod i livsstilsjournalistikkens og tv-underholdningens felt er serialiteten. Afgrænsningen indebærer dermed en frasortering af klassisk, tv-journalistisk udlandsdækning, som typisk består af enkeltstående temaudsendelser.

\section{Kodning og databehandling}

For at opbygge en grundlæggende, tilstræbt objektiv viden om centrale koncept- og produktionsforhold har vi screenet og kodet rejseserierne efter en række udvalgte parametre. Da værtsfunktionen spiller en central rolle for underholdningsaspektet i livsstils-formater, har vi valgt at kategorisere rejseserierne i forhold til, om programmet er værtsbåret eller ej, hvilket køn værten har, og om der er en eller flere værter pr. afsnit eller skiftende værter. Desuden har vi vurderet, om værten kan karakteriseres som en kendt mediepersonlighed i relation til kanalens målgruppe, da dette har betydning for seriens underholdningsaspekt. Videre har vi skelnet mellem rejseserier, der har rundrejsen i fokus, rejseserier, der fokuserer på en bestemt destination, 
og rejseserier, hvor rejseakten og destinationen er underordnet handlingen. Endelig har vi for at få klarhed over rejseseriernes produktionsforhold angivet, i hvilket land de er produceret. Foruden disse mere manifeste indholdsparametre har vi kodet serierne ud fra forhold, der er underlagt en højere grad af subjektiv fortolkning. Det drejer sig om vurderingen af, hvorvidt serien primært er skåret efter de dominerende principper inden for den journalistiske dokumentar, faktuel tv-underholdning, forbrugerorientering eller blandingsformer herimellem. Dette gør det muligt at sammenholde rejseseriens værtskabskonstruktion, rejsefokus og oprindelsesland med seriernes dominerende supertekstgenre, f.eks. vil rejseserieformater præget af faktuel tvunderholdning typisk prioritere handling over selve rejseakten og rejsemålet, fordi de ofte er spundet op omkring interaktion mellem kendte mediepersonligheder og derfor typisk danskproducerede til et dansk publikum. Kategoriseringen af, hvilken supertekstgenre hver enkelt rejseserie orienterer sig mod, lever ikke op til indholdsanalysens objektivitetskrav, men vi har brugt den som pejlingsmærke i forhold til analysens mønstergenkendelse af rejseserietyper og udført en interkoder-realiabilitetstest for at sikre resultatets gyldighed.

Forud for præsentationen af analysens fund af rejseserietyper vil vi kort skitsere udviklingen af rejseserierne på de danske kanaler i løbet af de 17 år, undersøgelsen strækker sig over.

\section{Analysens resultater: Historisk rids og fordeling af rejseserier på kanalerne}

Beregningen af det samlede antal rejseserier sendt på DR1, DR2, TV2, TV2 Zulu, TV2 Charlie og TV3 i perioden 1988-2005 viser, at udbuddet af rejseserier stiger kraftigt i periodens sidste del, som det fremgår af Figur 1. Fra første halvdel af perioden, 1988-1996, til sidste halvdel, 1997-2005, sker der en firedobling af det gennemsnitlige årlige antal rejseserier på de seks kanalers samlede sendeflade. Denne eksplosive udvikling i udbuddet af rejseserier hænger naturligvis sammen med opblomstringen af nye kanaler i det danske tv-landskab med en øget sendeflade til følge, men som Figur 2a viser, er der stor forskel på, hvor mange rejseserier hver af de seks kanaler udbyder årligt i perioden 1988- 
2005. Allerede i 1989, året efter lanceringen, melder TV2 sig på banen med tre forskellige rejseserier, mens DR1 kun sender en. Året efter opruster DR1 med tre rejseserier og sender i gennemsnit to rejseserier årligt, ca. 30 \% mere end TV2, frem til 1997, da DR's rejseserier overvejende flyttes fra DR1 til DR2. Først i det nye årtusinde begynder DR1 igen at sende mere end én rejseserie årligt, samtidig med at nye spillere melder sig på banen. En af dem er dansk TV3, der pludselig et årti efter sin lancering sender fire forskellige rejseserier i 2000, men herefter kun en enkelt i 2003. Ligeledes markerer ungdomskanalen TV2 Zulu for de 15-30 årige sig efter mindre end et år på banen med rejseserier fra 2001 til 2003, hvorefter de forsvinder fra prime time-sendefladen. Til gengæld tager det seneste skud på TV2-stammen, TV2 Charlie, over og tilbyder fra dag ét sin 50+ målgruppe et stort udvalg af rejseserier, nemlig fire i 2004 og hele otte forskellige i 2005.

En beregning af kanalernes gennemsnitlige udbud af rejseserier pr. år i perioden 1988-2005, som fremgår af Figur 2b, viser, at DR1 og TV2 i snit udbyder lige omkring to rejseserier pr. år, TV2 Zulu lidt mindre og TV3 få promiller, mens DR2 og TV2 Charlie udbyder lige omkring seks rejseserier pr. år. Undersøgelsen af de seks kanalers årlige udbud af rejseserier peger på, at rejseserier bliver afprøvet som prime time-underholdning på alle seks kanaler lige efter årtusindskiftet, på samme tidspunkt som discountflyselskaber som Ryanair får fodfæste i Danmark og andre europæiske lande og nærer drømmene om smutture til fjerne himmelstrøg med deres billigbilletter. Samtidig kommer nye kanaler og underholdningsformater til, og konkurrencen om publikum skærpes. Interessen for at udbyde rejseserier daler tilsyneladende igen hen mod slutningen af undersøgelsens periode, viser Figur 2a, og efterlader DR2 og TV2 Charlie som de helt store rejseserieudbyderne på den danske sendeflade, hvilket illustreres af, at de, bortset fra DRl's to rejseserier, er ene om at tilbyde rejseserier i 2005.

Et mere præcist billede af, hvor meget rejseserierne fylder på sendefladen, giver opgørelsen af, hvor mange rejseserieafsnit hver af de seks kanaler sender pr. år i perioden 1988-2005, som fremgår af Figur 3. Den understøtter den hidtidige analyse, da DR1's antal af rejseserieafsnit falder markant i årene efter DR2's lancering i 1996, mens DR2 og senere TV2 Charlie etablerer sig 
som rejsekanalerne på den danske sendeflade. TV2 Charlie overgår DR2, da man i 2005 sender ikke færre end 74 rejseserieafsnit, altså i snit næste to afsnit hver uge, mens DR2 topper med 59 rejseserieafsnit i 1999. En beregning af, hvor mange rejseserieafsnit hver af de seks kanaler sender gennemsnitligt på årsbasis i perioden 1988-2005, fremgår af Figur 4. Den viser, at DR1, TV2 og TV2 Zulu sender næsten lige mange rejseserieafsnit, nemlig lige omkring 10 pr. år, mens DR2 ligger på omkring 40 og TV2 Zulu sender knap 50 i snit på et år, altså i snit næsten et rejseserieafsnit hver uge.

Ser vi nærmere på den procentvise fordeling af, i hvilke lande de seks kanalers rejseserier er produceret i 1988-2005 som fremgår af Figur 5, viser det sig, at langt over halvdelen af kanalernes rejseserier stammer fra Danmark, mens lidt over en fjerdedel er produceret i Storbritannien, og der eksisterer få andre udenlandske produktioner. Det kan hermed konkluderes, at de fjerne, eksotiske rejsemål primært fremstilles af og for et dansk eller vesteuropæisk kulturfællesskab. Dog er der stor forskel på kanalerne, for mens TV2 Zulu og TV3 udelukkende og TV2 og DR1 fortrinsvist sender danskproducerede rejseserier, bringer TV2 Charlie og DR2 næsten lige så mange britisk- som danskproducerede rejseserier, og DR2 sender samlet set lidt flere engelsksprogede rejseserier end danske. En forklaring på TV2 Charlies og DR2's høje andel af engelsksprogede rejseserier er, at hjemmemarkedet ikke kan levere den mængde og type, som de to smalle kanaler efterspørger, og en anden, at produktionen af danske rejseserier er forholdsvist omkostningskrævende. Desuden hænger produktionsland som tidligere illustreret i nogen grad sammen med, hvilken rejseserietype der er tale om, da visse typer fordrer et nationalt indblik og andre et internationalt udsyn.

\section{0 forskellige rejseserietyper}

I løbet af vores empiriske analyse har vi arbejdet frem mod en mønstergenkendelse af forskellige rejseserietyper baseret på en kodning, sammenligning og kategorisering af de analyserede parametre, der er nærmere beskrevet i afsnittet om Kodning og databehandling. Resultatet af indholdsanalysen fremgår af Figur 6, der viser den samlede kategorisering af rejseserierne på DR1, 
DR2, TV2, TV2 Zulu, TV2 Charlie og TV3 i 1988-2005, idet kodningen af værtskabstype, produktionssted og rejsefokus sættes i relation til den dominerende supertekstgenre og udpeger de 10 rejseserieprototyper, vi har fundet dækkende for variationen i materialet. Da der netop er tale om prototyper, findes der varianter af rejseserier, som ikke opfylder alle variablene inden for en prototype. De fleste af materialets rejseserier må dog betegnes som klassiske eksempler på den kategori, de er blevet klassificeret som.

Den mest udbredte prototype i materialet er Den dokumentariske rejseserie, der, som navnet antyder, hører under supertekstgenren Journalistisk dokumentar og lægger sig op ad dokumentarfilmstraditionen ved at være udformet som en sagligt dokumenterende rejsebeskrivelse. Den dokumentariske rejseserie er værtsbåret og orkestreret som en rundrejse med et bestemt projekt for øje (af f.eks. antropologisk eller biologisk art), som typisk er drevet frem af en kendt, mandlig vært, som det fremgår af kodningsdata i Figur 6. Værten optræder som turguide, men nøjes sjældent med at forelæse on location, for oftest ser vi ham også interagere med og engagere sig i stedet, kulturen og befolkningen, eksempelvis ved at afprøve de attraktioner, stedet byder på, interviewe de lokale eller dele oplevelser med andre rejsende. Dermed lægger den dokumentariske rejseserie sig op ad den dokumentarfilmsmodus, som filmteoretikeren Bill Nichols (2001) har karakteriseret som den deltagende modus. Den dokumentariske rejseserie, som eksempelvis Michal Palin på verdens tag (seks afsnit, DR1, 2004), udgør majoriteten af rejseserierne på DR1 i den undersøgte periode, nemlig $67 \%$, og selv om den også optræder på de andre kanaler med undtagelse af TV2 Zulu, er den langt fra lige så hyppigt forekommende, som det fremgår af Figur 7, der udpeger den procentvise fordeling af rejseserietyper på hhv. DR1, DR2, TV2, TV2 Zulu, TV2 Charlie og TV3 i perioden 1988-2005.

Under supertekstgenren journalistisk dokumentar finder vi også en anden udbredt rejseserietype, nemlig Den populærvidenskabelige rejseserie, hvor fokus typisk rettes mod destinationen, f.eks. et bestemt geografisk områdes natur, naturfænomener, dyreliv eller historie, som det ses i f.eks. Silkevejen (TV2, 1989, 12 afsnit). Den populærvidenskabelige rejseserie er 
ofte orkestreret i tråd med Nichols' definition på en dokumentar i beskrivende modus (Nichols 2001:105). Her er information, oplysning og argument i centrum for rejsebeskrivelsen, der sædvanligvis ikke formidles af en synlig vært, men en voice-over, der understøttes af evidentiary editing, hvor billedsiden fortrinsvist bruges til at illustrere eller dokumentere det sagte. Den populærvidenskabelige rejseserie optræder hovedsageligt på DR1 og TV2 i begyndelsen af den undersøgte periode, men får efterfølgende stor udbredelse på DR2, f.eks. i form af DR's Explorer-serier lavet i samarbejde med Jyllands-Posten.

En helt anden type rejseserier er de, der domineres af supertekstgenren Faktuel tv-underholdning, hvor det sociale samspil og den visuelle nydelse er i centrum og sædvanligvis overordnet rejse og rejsemål. Her finder vi Den selskabelige rejseserie, der er en samlebetegnelse for en bred variation af formater, der rummer islæt af gameshow-, reality-, og makeover-tv og er særligt udbredt på TV3, TV2 Zulu og i nogen grad TV2, som det fremgår af Figur 7. I den selskabelige rejseserie placeres kendte eller ukendte i en iscenesat situation, f.eks. et socialt eksperiment, hvor to familier bytter ferie, som det sker i Rejsefeber (TV 2 Charlie, 2005, 17 afsnit), eller en konkurrence, hvor deltagerne skal løse bestemte opgaver et eksotisk sted, som det er tilfældet i Eventyrerne (TV2 Zulu, 2002, 10 afsnit). Den selskabelige rejseserie har hyppigt mere end en vært pr. afsnit og er ofte lokalt produceret til et nationalt publikum, der kender værterne og de kulturelle koder, som selskabeligheden udspiller sig inden for.

En mindre udbredt rejseserietype, som også hører under supertekstgenren Faktuel tv-underholdning, er Grupperejseserien, der følger et større selskab, typisk en familie, på en længere rundrejse, som det er tilfældet i Familien på farten (TV2 Charlie, 2005, otte afsnit). Her udgør omgivelserne i vidt omfang kulisse og afsæt for den kollektive dannelsesrejse, og fokus er på teamets sociale interaktion, i og med den fremmede kultur og ikke rejsen i sig selv eller rejsemålet er i fokus.

Rejsemålet er til gengæld i fokus i en anden, mindre udbredt rejseserietype, nemlig Reklamerejseserien, der hører under supertekstgenren Forbrugerorientering. Her er værten typisk erstattet af en voice-over, der argumenterer for bestemte destinationer og rejseformers nydelsesværdi gennem sansestimule- 
rende billeder og musik og fremhævelser af fristende forbrugsmuligheder i luksusklassen, som det er tilfældet i Drømmerejser (DR1, 1989, ni afsnit). Skønt denne rejseserie kun optræder få gange i det empiriske materiale, er det en rejseserietype, som er meget udbredt på internationale tv-kanaler som Travel Channel.

Supertekstgenren forbrugerorientering favner også Backpackerrejseserien, som udelukkende optræder på DR2, og her udgør den næsten en fjerdedel af kanalens rejseserier. Backpackerrejseserien skildrer den særlige rejsekultur, hvor uafhængige rejsende tager på en længere oplevelsesrejse til fjerne himmelstrøg. Den har, ligesom den dokumentariske rejseserie, en deltagende og opsøgende vært som narrativ motor, men i modsætning til denne, hviler backpackerrejseseriens programformat ikke på værtens persona, men på rejseritualet og -kulturen. Derfor opererer programmet med skiftende værter af begge køn, der sjældent er kendte mediepersonligheder forud for deres optræden i serien, men erfarne backpackere. Backpackerrejseserien udspiller sig i et forholdsvist fasttømret programformat med en udtalt forbrugerjournalistisk vinkling, der supplerer guidens display af stedernes kulturelle tilbud og menneskeflora med evaluering af low budget-oplevelser, spisesteder og overnatningsmuligheder. Produktionsselskaber som Pilot Guides, der også udgiver egne guidebøger, har specialiseret sig i dette internationale rejse-tvformat.

En anden forbrugerorienterende serietype er Aktivferie-rejseserien, der optræder på TV3, TV2 og i mindre grad DR2 og har en varieret værtskabskonstellation, som det fremgår af Figur 7. Aktivferie-rejseserien kredser om dyrkelsen af sport og friluftsliv, og derfor præsenteres, indtages og evalueres destinationen i overvejende grad i forhold til sin egnethed som kulisse for aktiviteten, som det eksempelvis er tilfældet i På ski igen (2000), hvor skiunderviser Thomas Uhrskov foruden at rådgive om sportsgrenen også leverer turistinformation og forbrugertips om skisportssteder.

Foruden de syv listede rejseserietyper, som er domineret af supertekstgenrerne journalistisk dokumentar, faktuel tv-underholdning og forbrugerorientering, fandt vi tre rejseserietyper, som lå i krydsningsfeltet mellem disse tre supertekstgenrer. Den mest udbredte er Den kulinariske rejseserie, som umiddelbart 
minder om den dokumentariske rejseserie, men hvor guiden ikke optræder som antropolog eller biolog, men som kok og kan være en kvinde eller et værtspar, men hyppigt er en kendt mandlig gourmet. Den kulinariske rejseserie er centreret om mad, egnsretter og lokal kogekunst typisk inden for et bestemt geografisk område, som titlen på en klassiker inden for denne rejseserievariant, Floyd i Australien (DR2, 1997, ni afsnit), indikerer. Med dette fokus på madkultur er serietypen ikke overraskende fraværende på TV3, der profilerer sig på kendis- og reality-formater, og TV2 Zulu, der har 15-30 årige som målgruppe, men den er til gængæld meget udbredt på DR2, TV2 og især på TV2 Charlie, hvor den udgør over $40 \%$ af kanalens rejseserier i den undersøgte periode, som det fremgår af Figur 7.

I krydsfeltet mellem de tre supertekstgenrer finder vi også Emigrant-rejseserien, der portrætterer enkeltpersoner eller familier, der har valgt at udvandre, og det sted, de har slået sig ned, f.eks. Når ude er hjemme (TV2 Charlie, 2005, seks afsnit). Her har historien om de medvirkendes omplantning og hverdagsliv i det fremmede en væsentlig plads, men den personlige beretning fungerer også som autenticitets- og troværdighedsmarkør for programmets turistguidefunktion: at fremstille den fremmede kultur gennem en hjemstavnsoptik.

Foruden de ni listede rejseserieprototyper, der dyrker rejsen, guider til eksotiske destinationer og bruger det fremmede som scene for social interaktion, findes der en atypisk rejseserie, Metarejseserien, som forholder sig reflekterende til eller direkte parodierer sin egen genre. Typisk er værtsrollen fiktiobiografisk, dvs. værterne spiller sig selv, hvilket er udtalt i I sandhedens tjeneste (1991, DR1, fem afsnit), eller værterne antager fiktive karakterer, som det er tilfældet i mockumentary-rejseserien Hold da helt ferie (1999, DR1, fem afsnit). Metarejseserien lægger sig dermed i forlængelse af Nichols' karakteristik af den refleksive dokumentarmodus (Nichols 2001: 125-137).

\section{Opsamling på empirisk analyse af rejseserier}

I artiklen har vi debatteret de teoretiske positioner, der beskæftiger sig med rejseserier, og argumenteret for nødvendigheden af at anskue og analysere rejseserier ud fra andre parametre end 
traditionelle nyhedsjournalistiske principper. I vores empiriske analyse har vi i stedet arbejdet med parametre, der er genstandssensitive over for tv-underholdningsformater, f.eks. programværtsrollen og turismekultur, f.eks. rejseformen, for at få en mere nuanceret tilgang til rejseserier som medieprodukt. Med afsæt i vores analyse vil vi argumentere for, at rejseserien er en hastigt transformerende og varieret hybridgenre udspændt i feltet mellem journalistisk dokumentar, faktuel tv-underholdning og forbrugerorientering. Derfor vil vi, som optakt til en afsluttende diskussion og perspektivering af analysens resultater, placere de 10 rejseserieprototyper i relation til deres anknytning til genrens tre supertekstgenrer. Ved hjælp af dette tentative, analytiske kompas er det muligt at karakterisere forekomster af nye hybride teksttyper inden for genren, tegne konturerne af tv-kanalernes rejseserieprofil og udpege relevante fremtidige forskningsområder i relation til rejseserien.

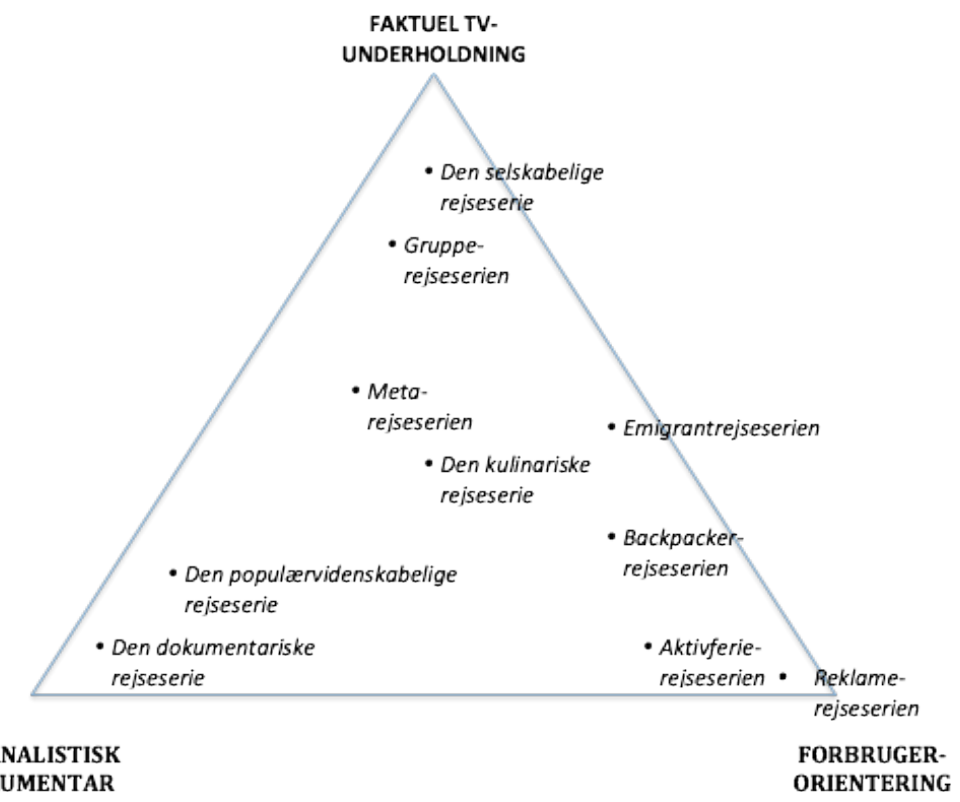

I modellens venstre hjørne, hvor de journalistiske principper dominerer, befinder den populærvidenskabelige og den dokumentariske rejseserie sig. Øverst i trekanten er rejseserierne primært underlagt den faktuelle tv-underholdnings principper, og her finder vi grupperejseserien og den underholdende rejseserie. 
Længst mod højre dominerer forbrugerorienteringens og reklamens principper, og her optræder reklame-, aktivferie- og backpackerrejseserien. I modellens midte er den kulinariske rejseserie samt emigrant- og metarejseserien placeret, da disse ikke er domineret af nogle af yderpolerne.

Med udgangspunkt i denne model bliver det også muligt at beskrive konturerne af de seks kanalers forskellige kanalprofil i forhold til deres satsning på rejseprogrammer. Supertekstgenren nyhedsjournalistik er mest dominerende på DR2 og DR1, men præger også en del af rejseserieudvalget på TV2, hvorimod supertekstgenren faktuel tv-underholdning dominerer TV2 Zulu, en stor del af TV3- og en mindre del af TV2-udbuddet. Supertekstgenren forbrugerorientering præger sendefladen på TV2 Zulu og i mindre grad TV2 og DR2, mens alle kanaler med undtagelse af TV3 i større eller mindre omfang udbyder rejseserier, der befinder sig i modellens midte.

En svaghed ved vores empiriske analyse er, at den er afgrænset til danske tv-kanaler, hvorfor de prototyper, vi finder, primært er dækkende for en dansk og skandinavisk mediekultur og ikke umiddelbart generaliserbare i forhold til andre nationers tv-sendeflader. Det er således muligt, at der findes rejseserietyper inden for andre kulturelle fællesskaber, som ikke er dækket af vores undersøgelse. Til gengæld kan vi sandsynliggøre, at de rejseserieprototyper, vi har kortlagt, også findes i andre lande, da der med undtagelse af grupperejseserien inden for hver kategori findes en eller flere serier, der er produceret i udlandet. Den fremtidige forskning i rejseserier bør uddybe feltet videre med komparative analyser af rejseserier sendt på hhv. danske og udenlandske kanaler samt teoretiske diskussioner af hhv. generiske og hybride træk ved rejseserier.

\section{Diskussion: rejse som underholdende journalistik}

Vores undersøgelse af rejseserien som genre og medieprodukt på den danske sendeflade tager afsæt i en teoretisk refleksion over rejseseriers journalistiske aspekter og er dermed ikke blot et bidrag til opdyrkning af den fremspirende forskning i rejseserier, men også et indspark til nuancering af forskningen i rejsejournalistik. Gennem vores undersøgelse har vi sandsynliggjort, at rej- 
seserierne har rødder i rejsejournalistikken, men må karakteriseres som en facetteret audiovisuel genre, der har underholdning som præmis og kendetegn.

Rejsejournalistik udfolder sig både på internettet, i magasiner, dagspresse og tv, men typisk er det livsstilsmagasinernes måde at præsentere og formidle stoffet på, der er forbilledet. Det vil sige en billedbåren journalistik, der har nydelse og nytte som primære publikumsappeller. I rejsejournalistik er fokus dels på destinationer og kulturer, der kan forbruges, dels på bestemte rejsemåder og turismeformer. Rejse- og livsstilsjournalistik er karakteriseret ved at indeholde klare reklameelementer: praktiske oplysninger om konkrete rejsemål, referencer til rejseudbydere samt fristende fremstillinger af destinationer og rejseformer. Dermed er rejsejournalistikken, ligesom livsstilsjournalistikken, udspændt mellem forbrugerorientering, underholdning og journalistik.

En væsentlig problematik, som vores undersøgelse rejser, er, hvad der adskiller rejseseriegenren fra andre former for tv-underholdning, der også indeholder rejseelementer, f.eks. Paradise Hotel (TV3) eller Guider i Paradis (TV2)? En afgørende distinktion er, hvorvidt rejseserien har rejsen, turguidning eller et turist-blik på steder (Urry 2002) som en konstituerende del af sit koncept og f.eks. ikke er en rendyrket reality-serie som Paradise Hotel eller dokusoap-serie som Guider i Paradis eller et element i et boligprogram som f.eks. Hammerslag i Spanien (DR1). Som Annette Hill (2007) påpeger, er faktuel tv som felt og fænomen kendetegnet ved netop hele tiden at blande genreelementer, bryde konventioner og variere og skabe nye genre-crossovers, og det kan derfor være svært og også misvisende at forsøge at indfange og fastholde en genre som rejseserier. På den anden side agerer rejseserier hele tiden i forhold til disse genrekonventioner og fastholder dermed genrekontrakten med seerne. Disse vilkår betyder, at vores undersøgelse rummer grænsetilfælde, hvis rubricering som rejseserie kan diskuteres, da serien med rimelighed også kan kategoriseres som f.eks. madprogram eller realityserie. Vi har forsøgt at imødegå denne problematik ved at arbejde med prototyper og inkludere genrehybrider, hvor rejsen udgør mere end kulisse ved at indgå i seriens grundlæggende struktur og præmis.

Ved at betragte rejseserier og rejsejournalistik som en del af 
det kulturjournalistiske felt bliver det tydeligt, at der er tale om et område, som har betydeligt omfang og desuden omfatter forskellige journalistiske blandingsformer både på tekstniveau og redaktionelt niveau, der bryder med traditionelle (nyheds)journalistiske idealer og genrer. Men hvad skal vi så forstå ved journalistik, når nyhedsmedierne i stigende grad præges af rejse- og livsstilsstof, og klassiske nyhedskriterier, evidens og kildevurdering må vige tilbage for sanseprægede fortællinger, praktiske guider og nydelsesfulde billeder? En måde at besvare dette spørgsmål på er netop at betragte journalistik som forskellige diskursive praksisfelter, f.eks. ved at sondre mellem ulandsreportager (som en del af nyhedsjournalistik) og rejsejournalistik (som en del af kulturjournalistik). Som vi har set, udgør underholdende journalistik et særligt felt, der dominerer mediernes indhold og indeholder specifikke kommunikative præmisser og redaktionelle intentioner. Vores analyse illustrerer, hvordan rejseserier blander elementer fra henholdsvis den journalistiske dokumentar, forbrugerorientering og faktuel tv-underholdning og indgår i fjernsynets underholdende hverdagsflade.

MAJA SONNE DAMKJAER, cand.mag., ph.d.-studerende ved Institut for ÆEstetik og Kommunikation - Informations- og medievidenskab (pr. 1. feb. 2012), Aarhus Universitet, imvmsd@hum.au.dk

ANNE MARIT WAADE, ph.d., Lektor, Institut for AEstetik og Kommunikation Informations-og medievidenskab, amwaade@hum.au.dk

\section{LITTERATUR}

Bell, David \& Hollows, Joanne (eds) (2005). Ordinary Lifestyles - Popular

Media, Consumption and Taste, Glasgow, Open University Press.

Bonner, Frances (2003). Ordinary Television, London, Sage.

Bruun, Hanne og Frandsen, Kirsten (2010). Underholdende TV, Aarhus , Aarhus Universitetsforlag.

Christensen, Christa Lykke (2010). "Livsstilsprogrammer", in: Bruun \& Frandsen: Underholdende TV, Aarhus , Aarhus Universitetsforlag.

Christensen, Christa Lykke (2009). "Livsstil som tv-underholdning" in Mediekultur - journal of media and communication research, No. 45, pp. 23-36. 
Crouch, David, Jackson, Rhona, \& Thompson, Felix (2005). The media and the tourist imagination, London, New York, NY: Routledge.

Dunn, David (2005a). Playing the tourist, in: David Bell \& Joanne Hollows: Ordinary Lifestyles - Popular Media, Consumption and Taste, Milton Keynes, Open University Press.

Dunn, David (2005b). ”We are not here to make a film about Italy, we are here to make a film about ME...”, in: Crouch, D., Jackson, R. \& Thompson, F: The Media \& the Tourist Imagination, London, New York, NY, Routledge.

From, Unni (2007). "Forbruger- og livsstilsjournalistik - en analyse af nytte og nydelse i journalistikken”, in: Mediekultur No. 42/43-2007, Aarhus.

From, Unni \& Waade, Anne Marit (2007). "Smagfulde fremstillinger Oplevelsesmatricer i mad- og rejselivsjournalistik”, in: Journalistica, Vol. 4/2007, Aarhus, AJOUR.

From, Unni \& Kristensen, Nete Nørgaard (2011) Kulturjournalistik journalistik om kultur, Samfundslitteratur.

Fürsich, Elfriede (2002a). "How can global journalists represent the 'Other"?' in: Journalism 3(1), Sage.

Fürsich, Elfriede (2002b). "Packaging Culture: The Potential and Limitation of Travel Programs on Global Television", Communication Quarterly, Vol. 50 No. 2 Spring, Routledge

Hanitzsch, Thomas (2007). ”Deconstructing Journalism Culture, toward a universal theory", Communication Theory No. 17, pp. $367-385$ Blackwell Publishing, Inc.

Hanusch, Folker (2010). ”The dimensions of travel journalism”, Journalism Studies Vol. 1/2010, Routledge.

Hill, Annette (2007). Restyling Factual TV, Abingdon, England, New York, Routledge.

Jensen, Jakob Linaa \& Waade, Anne Marit (2009). Medier og turisme, Aarhus, Academica.

Kabel, Lars (2005). Verden langt herfra - en analyse af nyheder og faktaprogrammer i dansk tv, rapport udarbejdet på opdrag for Danida, udgivet af Center for Journalistisk Efteruddannelse, Aarhus (findes online).

Kabel, Lars (2006). "Journalistik om flere af verdens virkeligheder", in: Journalistica No. 2/2006, Aarhus, AJOUR, pp. 67-83.

Lischke, Joanna (2006). "Reisejournalisten: Akteure im Spannungsfeld", University of Munich, MA thesis. 
Nichols, Bill (2001). Introduction to Documentary, Indiana University Press, Bloomington \& Indianapolis.

Orgeret, Kristin Skaret (2002). “Med gutta på tur; Blikk på verden i TV2's reiseprogram”, in: Enli, Syvertsen \& Østby Sæther (red.): Et hjem for oss - et hjem for deg? Analyser av TV2 1992-2002, Oslo, Ij-forlaget AS.

Palmer, Gareth (2008). Exposing lifestyle television: the big reveal, Aldershot, England, Burlington, VT, Ashgate.

Povlsen, Karen Klitgaard (2007). "Smag, livsstil og madmagasiner", in: Mediekultur, Vol. 42-43/2007, Aarhus.

Scannell, Paddy (1994). "Kommunikativ intentionalitet i radio og fjernsyn", Mediekultur, No. 22, Aarhus, pp. 30-41.

Urry, J. (2002). The Tourist Gaze - Leisure and travel in Contemporary Societies, 2nd edition, London, Thousand Oaks, California, Sage Publications (1. ed. 1990).

Waade, Anne Marit (2009). "Travel Series as TV Entertainment", in: Mediekultur, No. 46/2009, Aarhus.

Waade, Anne Marit (2010). "Rejseserier: TV med udsigt”, in: Bruun, Hanne og Frandsen, Kirsten (2010). Underholdende TV, Aarhus , Aarhus Universitetsforlag. 


\section{Figur 1:}

Figur 1. Samlede antal rejseserier pr. år sendt på DR1, DR2, TV2, TV2 Zulu, TV2 Charlie og TV3 i perioden 1988-2005

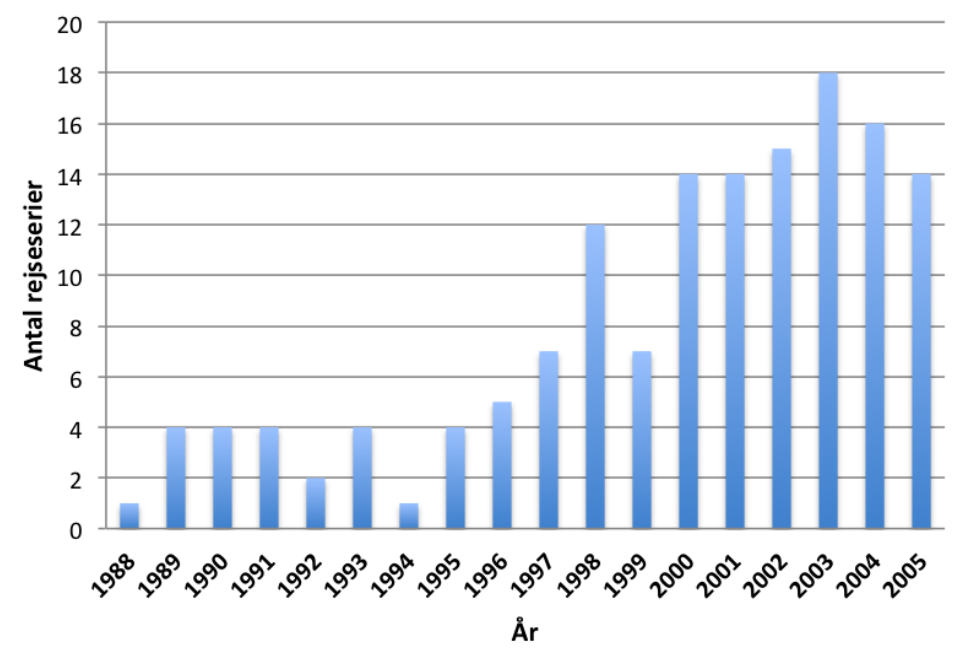

Figur 2a:

Figur 2a. Antal rejseserieafsnit sendt årligt på hhv. DR1, DR2, TV2, TV2 Zulu, TV2 Charlie og TV3 i perioden 1988-2005

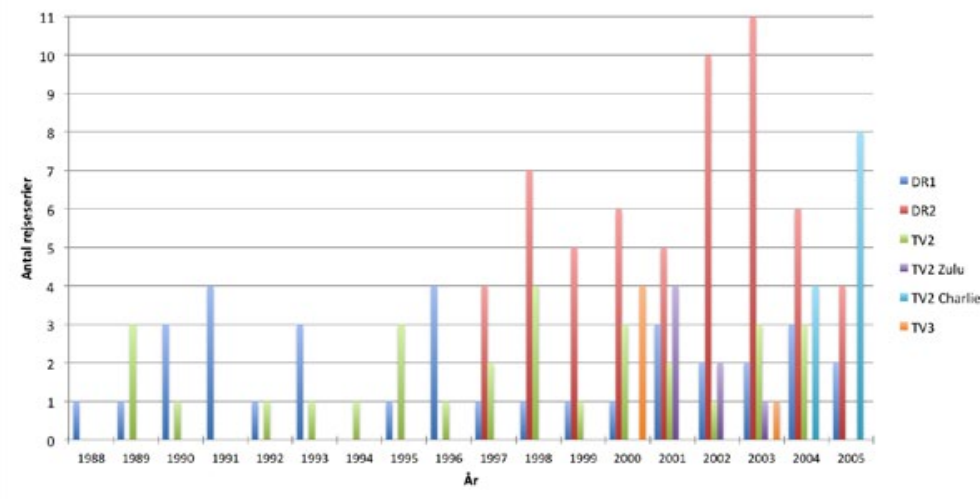


158 // JOURNALISTICA - NR. 1 2011

\section{Figur 2b:}

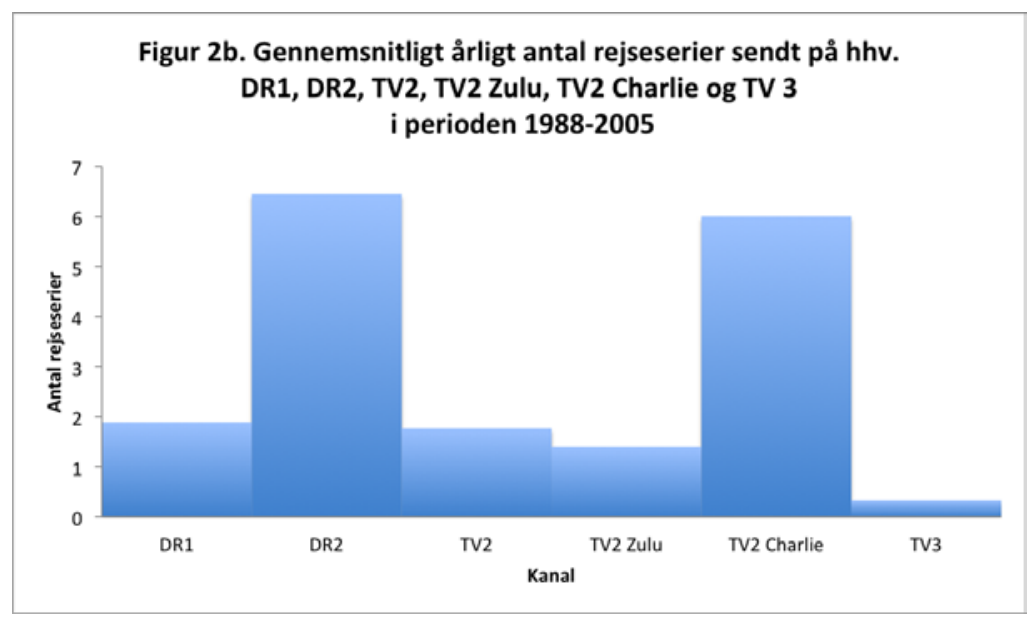

Figur 3:

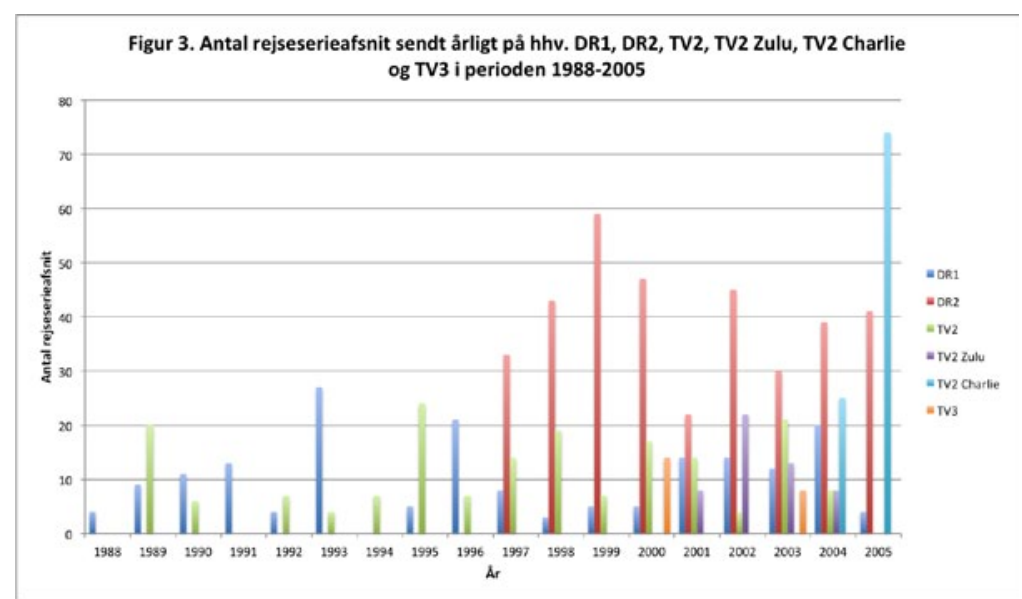


Figur 4:

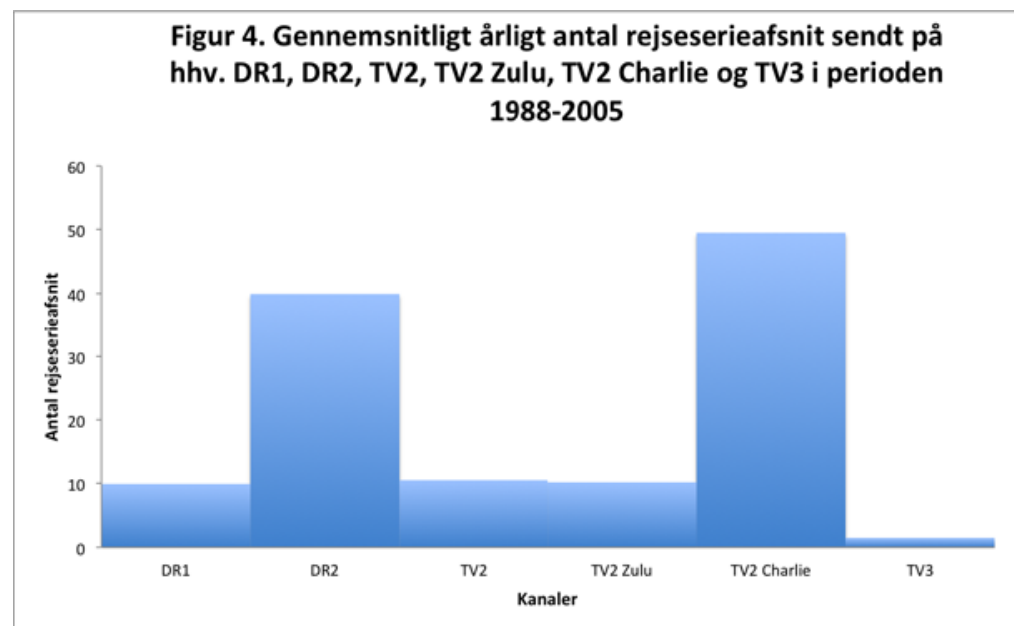

Figur 5:

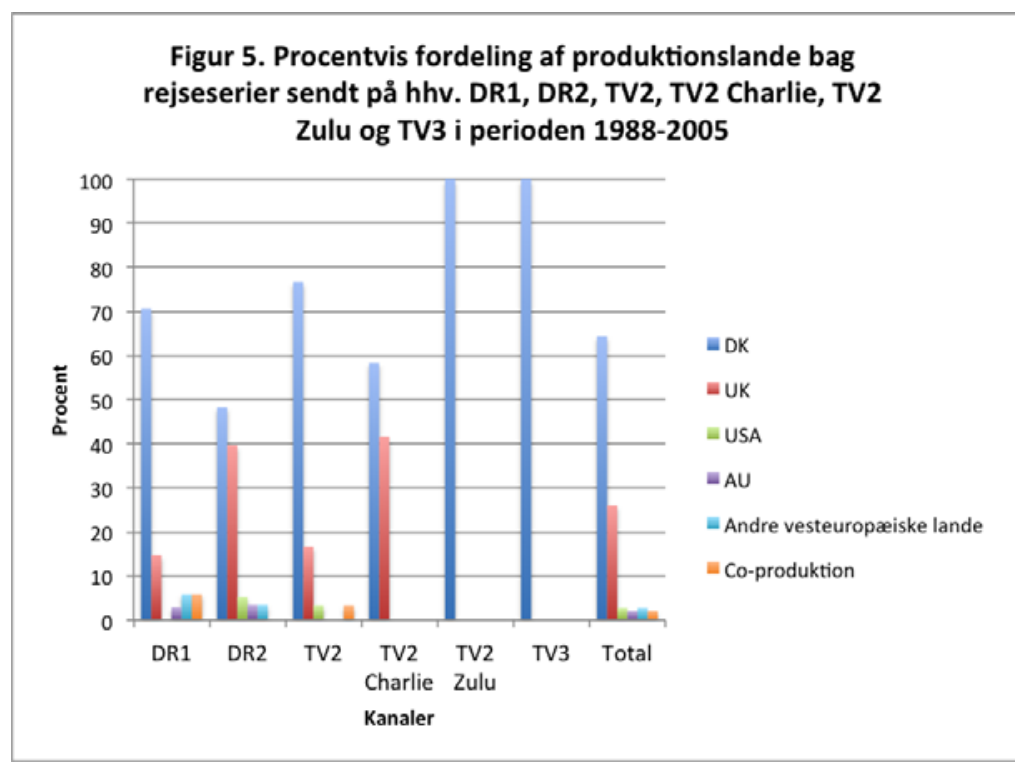


Figur 6:

HGUA6: Fesultat af indholdsanalysen at rejseserier pa DFI, DFe, TV2, TV2 Zulu, TV2 Charlie of TV3 tra 1988-2005.

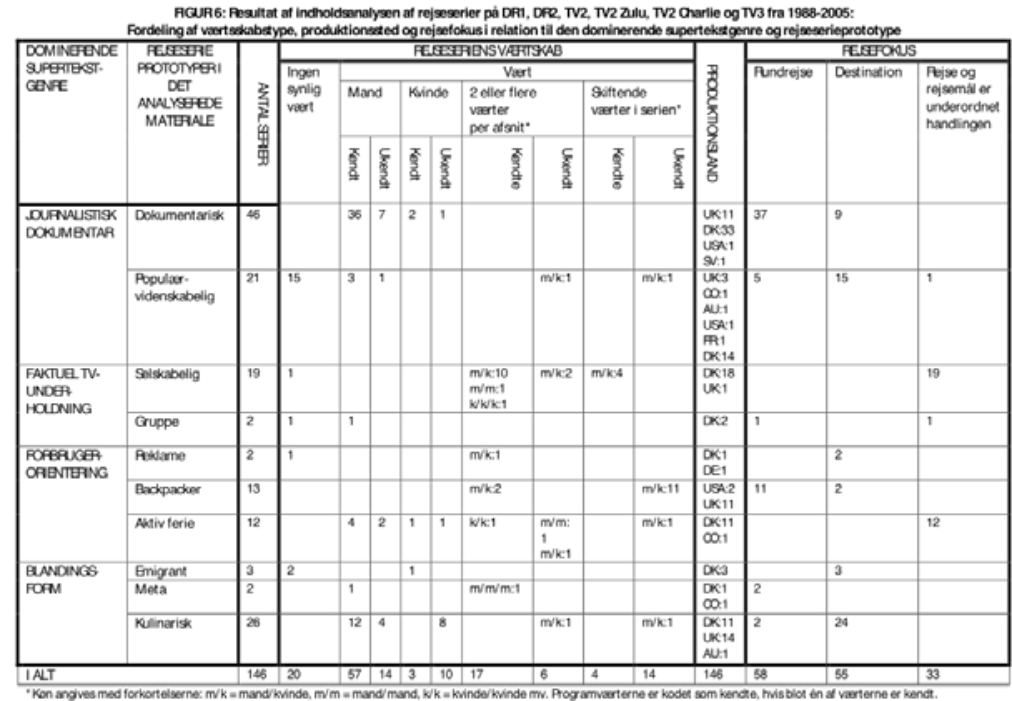

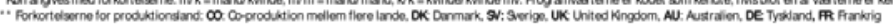

Figur 7:

Figur 7. Procentvis fordeling af rejseserietyper på

hhv. DR1, DR2, TV2, TV2 Zulu, TV2 Charlie og TV3 i perioden 1988-2005

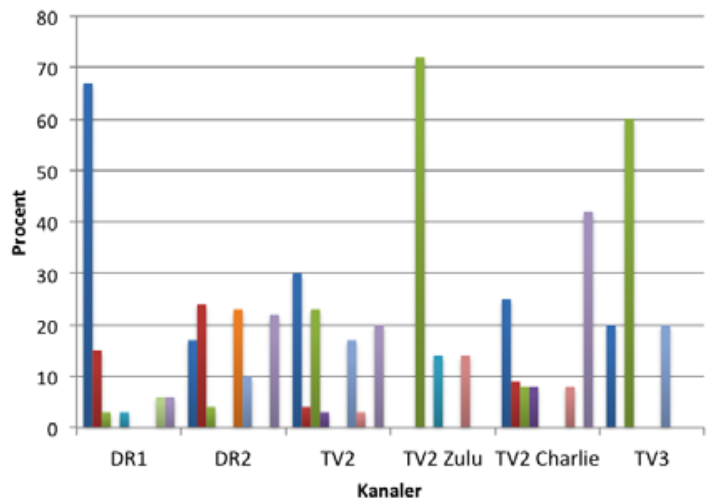

Dokumentarisk

- Populærvidenskabelig

= Selskabelig

-Gruppe

= Reklame

Backpacker

= Aktiv ferie

Emigrant

Meta

Eulinarisk 
1 Registranten er udarbejdet i forbindelse med forskningsprojektet Tvunderholdning: tværmedialitet og viden (FKK, 2006-2009) og findes online: http://tvunderholdning.au.dk

2 Derved er udlandsdokumentar-serier, f.eks. TV2's korrespondentserie Min By (TV2, 1997, fem afsnit) og DR-Explorer: Klimavidner i Afrika (DR2, 2004, fire afsnit), samt serier centreret om natur- og dyreliv, f.eks. Ude i naturen: Vildmark Fiske-special (DR2, 2002, to afsnit), eller traditionelle journalistiske dokumentarserier med et rejseislæt, f.eks. Livet ombord (DR1, 2002, fire afsnit), frasorteret. 